Cita: Passero, J. G.; Barreira, J.; Caldeirani Junior, A.; Galatti, L. R. (2019). Gender (in)equality: a longitudinal analysis of women's participation in coaching and referee positions in the Brazilian Women's Basketball League (2010-2017). Cuadernos de Psicología del Deporte, Vol 19(1), 252-261

\title{
Gender (in)equality: a longitudinal analysis of women's participation in coaching and referee positions in the Brazilian Women's Basketball League (2010-2017)
}

\section{(Des)Igualdad de género: un análisis longitudinal de la participación de las mujeres en los roles de entrenadora y arbitraje en la Liga Brasileña de Baloncesto Femenino (2010-2017)}

\section{(Des)Igualdade de gênero: uma análise longitudinal da participação das mulheres em cargos de comissão técnica e arbitragem na Liga Brasileira de Basquetebol Feminino (2010-2017)}

\author{
Passero, J. G. ${ }^{1}$, Barreira, J. ${ }^{2}$, Calderani Junior, A. ${ }^{1}$, Galatti, L. R. ${ }^{1}$ \\ ${ }^{1}$ School of Applied Science, University of Campinas, Limeira, São Paulo, Brazil; ${ }^{2}$ School of Physical \\ Education, University of Campinas, Campinas, São Paulo, Brazil
}

\begin{abstract}
The aim of this study was to analyze the participation of women in coaching and referee positions in the Brazilian Women's Basketball League, from the first edition of the championship (2010) to the moment of the present study (2017). For this proposal, we analyzed the sex of the coaching staff and referee crews from all the matches played in this period. All data were collected from the official match reports, accessed at the League headquarters. The results showed that women represent $24 \%$ of the head coaches, and this proportion has remained stable over the past years. However, it was found that women's participation as assistant coaches dropped from 88\% (2010) to 34\% (2017). Although, the participation actually increased for women in the positions of referee, umpire 1 and umpire 2, over the past seven years, these positions are still mostly occupied by men. A higher participation of women could be found in scorer and timekeeper positions, which also remained stable over the years. Although women's participation in sports, and specifically in elite Brazilian basketball, has been increasing in the last decades, the findings of this study showed that occupations for women, within basketball are still restricted to positions of less visibility. Men still mostly occupy the positions of leadership, as head coaches and referees. The results suggest the need for debate and proposals of policies, to promote female participation in different leadership positions in basketball.
\end{abstract}

Keywords: Coaching staff. Referee. Women basketball. Inequality. Gender.

Correspondence to: Larissa Rafaela Galatti. School of Applied Science, University of Campinas. R. Pedro Zaccaria, 1300, Limeira, São Paulo, Brazil E-mail:

larissa.galatti@fca.unicamp.br 


\section{(In)equality in coaching and referee in the Brazilian women's basketball}

\section{RESUMEN}

El objetivo de esta investigación fue analizar la participación de las mujeres en los roles de entrenadora y árbitra en la Liga Brasileña de Baloncesto Femenino desde la primera edición de la competición (2010) hasta el momento de esta investigación (2017). Para esa propuesta, se analizó el sexo del cuerpo técnico de ambos equipos y de los miembros del equipo de árbitros de todos los partidos jugados en este período. Todos los datos se recopilaron en los informes oficiales de partidos a los que se accedió en la sede de la Liga. Los resultados mostraron que las mujeres representan el $24 \%$ de los entrenadores y esta proporción se ha mantenido estable en los últimos años. Por otro lado, se encontró una disminución en la participación de las mujeres como entrenadora asistente del 88\% (2010) al 34\% (2017). Aunque hubo un pequeño aumento en la participación de las mujeres como árbitras, la árbitra 1 y la árbitra 2 a lo largo de los años, estos puestos siguen ocupados en su mayoría por hombres. Se pudo encontrar una mayor participación de mujeres en los puestos de anotadores y cronometradores que se mantuvieron estables a lo largo de los años. Aunque la participación de las mujeres en el deporte, y específicamente en el baloncesto femenino de élite brasileño, ha aumentado en las últimas décadas, los hallazgos de esta investigación mostraron que esta ocupación se restringe a los puestos de menor visibilidad. Los hombres ocupan principalmente los puestos de liderazgo, como entrenadores y árbitros. Esta investigación refuerza la necesidad del debate y la propuesta de políticas para promover la participación femenina en diferentes posiciones de liderazgo en el baloncesto.

Palabras clave: Cuerpo técnico. Árbitro. Baloncesto femenino Desigualdad. Género.

\section{RESUMO}

O objetivo deste estudo foi analisar a participação das mulheres em cargos de comissão técnica e de arbitragem na Liga Brasileira de Basquete Feminino (LBF) desde a primeira edição do campeonato (2010) até o momento deste estudo (2017). Para essa proposta, analisamos o sexo dos profissionais de ambos os times e dos membros da equipe de arbitragem em todos os jogos disputados nesse período. Todos os dados foram coletados nos relatórios oficiais das partidas acessados na sede da Liga. Os resultados mostraram que as mulheres representam $24 \%$ dos treinadores e essa proporção permaneceu estável nos últimos anos. Por outro lado, verificamos uma diminuição na participação das mulheres como assistentes técnicas de 88\% (2010) para 34\% (2017). Embora encontramos um pequeno aumento na participação das mulheres como árbitras, fiscal 1 e fiscal 2 ao longo dos anos, estas posições ainda são ocupadas principalmente por homens. Uma maior participação das mulheres pode ser encontrada nas posições de apontador e cronometrista, as quais se mantiveram estáveis ao longo dos anos. Embora a participação feminina no esporte, e especificamente no basquete brasileiro de elite, tenha aumentado nas últimas décadas, os achados deste estudo mostraram que essa ocupação ainda está restrita às posições de menor visibilidade. Os homens ainda ocupam majoritariamente as posições de liderança, como treinadores e árbitros. Esse estudo reforça a necessidade do debate e da proposta de políticas que promovam a participação feminina em diferentes posições de liderança no basquete.

Palavras chave: Comissão Técnica. Arbitragem. Basquetebol Feminino. Desigualdade. Gênero.

\section{INTRODUCTION}

The literature has suggested that women have been marginalized, discriminated against, and undervalued in workplace leadership positions in sports (Kane \& Stangl, 1991; Norman, 2010b; Sartore \& Cunningham, 2007). In basketball, for example, several studies investigated the discrimination and prejudice faced by female coaches. Walker, Bopp and Sagas (2011) revealed that, despite perceptions of more than capable abilities and job-fit, women are still offered a men's college basketball coaching job less often than are men. Similarly, Kalin and Waldron (2015) showed that preferences for male coaches still exist in NCAA Division I women's basketball.
Cunningham and Sagas (2002) suggested that human capital had different effects for men and women, thereby prompting the diminished expectations and early exit intentions of women in coaching positions in basketball. At last, Wellman and Blinde (1997) highlighted the degree to which homophobia and lesbian labels impact key aspects of the coaching context of women's basketball. Although these studies constituted an important debate regarding gender inequality in sports workplaces in the United States, the investigation of female participation in other leadership positions in basketball, as well as in other cultural contexts, could bring new insights for this debate and a broader look at the phenomenon. 


\section{Passero, J. G., Barreira, J., Caldeirani Junior, A., Galatti, L. R.}

The underrepresentation of women in coaching positions has been widely investigated. As an example, a study in 2009 found that women represented only $20 \%$ of the Canadian coaching in Canadian Interuniversity Sports (Reade, Rodgers, \& Norman, 2009). In the United Kingdom, the representation of female coaches in all the female national teams is only 4\% (Norman, 2010a). In Brazil, only $7 \%$ of the head coaches in different sports are female (Ferreira, Salles, Mourão, \& Moreno, 2013). Theberge (1993) suggested that, of all positions in sports, coaching captures the central features of the stereotypical view of 'sport', as masculine. The power and visibility tied to the coaching position leads coaching to be an area with the most significant gender imbalance in sports (Hargreaves, 1994). The explanation for the male dominance in coaching seems, then, in one way or another to be embedded in the culture of sports, and related to the gender power structure in both society and athletics (Fasting, 2000).

Kilty (2006) suggested that women coaches face four external barriers: (1) unequal assumptions of competence, (2) hiring from a principal of similarity, (3) homophobia, and (4) lack of female mentors. According to the author, there is an unequal assumption that male coaches are more competent than female coaches. Consequently, a female coach always feels the need to prove herself. Secondly, there is a tendency for people to hire individuals similar to themselves, as it is the easiest and most comfortable thing to do (Kanter, 1993; Stangl \& Kane, 1991). Therefore, male coaches and directors tend to hire more men for leadership positions in sports, reinforcing the vicious cycle. Homophobia is also a barrier faced by female coaches. The male-dominated arena, coupled with the heterosexist atmosphere, leads women to be discriminated against, and perceived as lesbian in leadership positions in sports. Finally, it is suggested that the lack of female role models may discourage young girls from pursuing leadership positions in sports. According to Everhart and Chelladurai (1998) female athletes with women coaches perceive less discrimination and are more interested in coaching positions than are those coached by males.

Although the four barriers described above were investigated in the coaching context, it may be speculated that the same constraints are faced by women in many others leadership positions in sports. In this way, Walker and Bopp (2010) suggested several factors that may prevent women from obtaining, maintaining, and increasing their representation in leadership positions in sports based on the findings of previous studies. The authors identified several factors which reduce female leadership participation: 1) the lack of mentoring and female role models, 2) gender-role stereotyping, 3) over-sexualization and marginalization of women by the media, 4) intention-related variables, such as the tendency to hire individuals similar to oneself. In summary, many of the inequalities suffered by women are due to the traditional ideology of male hegemony in sports (Norman, 2010b).

Despite the extensive research on women's coaching and administrative positions, there are few studies focusing on women's participation as officials, another important leadership position in a sports workplace. Forbes, Edwards and Fleming (2015) suggested that the perceptions of female officials in soccer were widely based on gender stereotypes. Women found their competence as officials questioned even before they had entered the field of play. A possible reason is because the association between authority and masculinity still has great force in the perception of people (Norman, 2010b). In the same way, Edwards (2013) argue that 'reference to such purported differences to justify the exclusion of women from roles such as officiating is unfounded and sexist'. As a result, the women put themselves under increased pressure to get decisions right, and to rebut the misconception that females cannot referee (Forbes et al., 2015).

Most of the studies on women officials, and also on women coaches, were conducted in the context of soccer. Basketball is also an interesting case to be studied, due to its higher prevalence of women in leaderships positions compared to other sports. For example, in the United States, $65.8 \%$ of the assistant coaches in women's basketball and $57.4 \%$ of the head coaches in women's basketball were female, according to a 2010 study (Walker \& Bopp, 2010). In Division I Women's Sports, Welch and Sigelman (2007) found that women coaches are most prevalent in basketball compared to volleyball, soccer and softball. Although the representation of women in the sports workplace, and more specifically in basketball, 


\section{(In)equality in coaching and referee in the Brazilian women's basketball}

is well-known in the United States, it may differ in other societies and cultural contexts, due to their particular social constructions and structural and symbolic gender arrangements. Therefore, it is necessary to find out if this participation of women as head coaches and assistant coaches in basketball follows the same pattern in other cultural contexts, as well as in other positions, such as officials.

In Brazil, the discussion about women in athletic leadership positions has received more attention, over the past five years. Most national studies investigated the challenges and pathways faced by women coaches in soccer (Novais, 2018; Vargas, Caputo, \& Silva, 2017; Wolf, 2017). This greater interest in soccer may reflect the greater popularity of the sport in the country. Although basketball is not as popular as soccer in Brazil, the women's basketball national team was recognized for its performance in the 1990s. In that decade, the Brazilian national team reached the pinnacle of excellence by winning the women's basketball World Championship in Australia in 1994, followed by two Olympic medals - silver medal in Atlanta 1996 and bronze medal in Sydney 2000 (Galatti et al., 2015). Since then, the sport has gone through its ups and downs. An important event in recent years was the creation of the Brazilian Women's Basketball League (in Portuguese, Liga de Basquete Feminino or LBF) in 2010. The championship for that league has been played every year since its creation, and is composed of the top women's basketball teams in the country.

Just as longitudinal analysis has been conducted to investigate the proportion of women in leadership positions, throughout the years, in both the United States (Acosta \& Carpenter, 2002; Darvin \& Sagas, 2017) and Spain (Fernández \& Ventura, 2007), a similar study could be conducted in the Brazilian territory, to investigate the interesting case of women's basketball. Darvin and Sagas (2017) suggested some advantages of conducting this type of longitudinal analysis. One possible benefit is the capability of this kind of study to reveal changes, for better or for worse, in the proportion of women in athletic leadership positions. It is also possible to analyze the longitudinal effects of sports policies on women's participation in sports workplaces. Finally, these replication studies can provide researchers with a consistent flow of current trends and patterns into the presence of women in leadership positions in sports.

Therefore, the main goal of this study was to analyze the participation of women in coach and referee positions in the Brazilian Women's Basketball League (LBF). As a specific objective, we aimed to analyze the longitudinal participation of women as coaching staff and referees, throughout the 2010 to 2017 seasons. The results of this study could provide a better understanding of women's participation in leadership positions in basketball, and also improve the discussion on gender (in)equality in sports in Brazil. The implications of this study could lead to a greater debate, regarding the opportunities and access for women in coaching and referee positions in the world of elite women's basketball, and to (re)think the stereotypes in sports workplaces.

\section{METHODS}

\section{Data collection}

The match reports of the Brazilian Women's Basketball League were used for data collection. The official match reports were accessed at the League Headquarters. Despite the high turnover of the coaching staff and members of the referee crew throughout the seasons, data of all the matches played from 2010 to 2017 were collected. The League was created in 2010, which is why this was the first year of data collection. The upper limit of data was set based on the most recent season, in 2017. From each match, the names of the coaching staff of both teams and of the members of the referee crew were collected. The sex of each professional was defined, based on his or her name. Information available on social networks was used to confirm the sex classification. Two types of coaching staff were investigated in this study: head coaches and assistant coaches. Regarding the referee positions, the sex of the referee, umpire 1 , umpire 2 , scorer, timekeeper and $24 \mathrm{~s}$ operator were also analyzed.

\section{Statistical analysis}

All data were arranged in Microsoft Excel spreadsheets and exported to MATLAB 2010, the software that was used for all the statistical analysis. Data was summarized in relative frequency. The $\chi^{2}$ test was used to compare the frequency of men and women 


\section{Passero, J. G., Barreira, J., Caldeirani Junior, A., Galatti, L. R.}

in each professional position. The level of significance was set as 0.05 . The Pearson's correlation coefficient was used to analyze women's participation in coach and referee positions, throughout the years. Due to the low number of seasons analyzed in this study and the

\section{RESULTS}

In all, 501 matches were analyzed and information from 4825 coaching staff and referee crews was collected. Figure 1 shows the frequency of male and female participation in each position, during the influence of sample size on the significance of correlation analysis, the correlation coefficient was interpreted as small correlation $0.1<|\mathrm{r}| \leq 0.3$; medium correlation $0.3<|\mathrm{r}| \leq 0.5$ and large correlation $0.5<|\mathrm{r}|$ $\leq 1.0$ (Cohen, 1988).

course of the seven seasons. Men have a significantly higher participation, compared to women as head coach, referee, umpire 1 and umpire 2. A higher participation of women could be found for scorer and timekeeper positions. Men and women were found equally, amongst assistant coaches and $24 \mathrm{~s}$ operators.

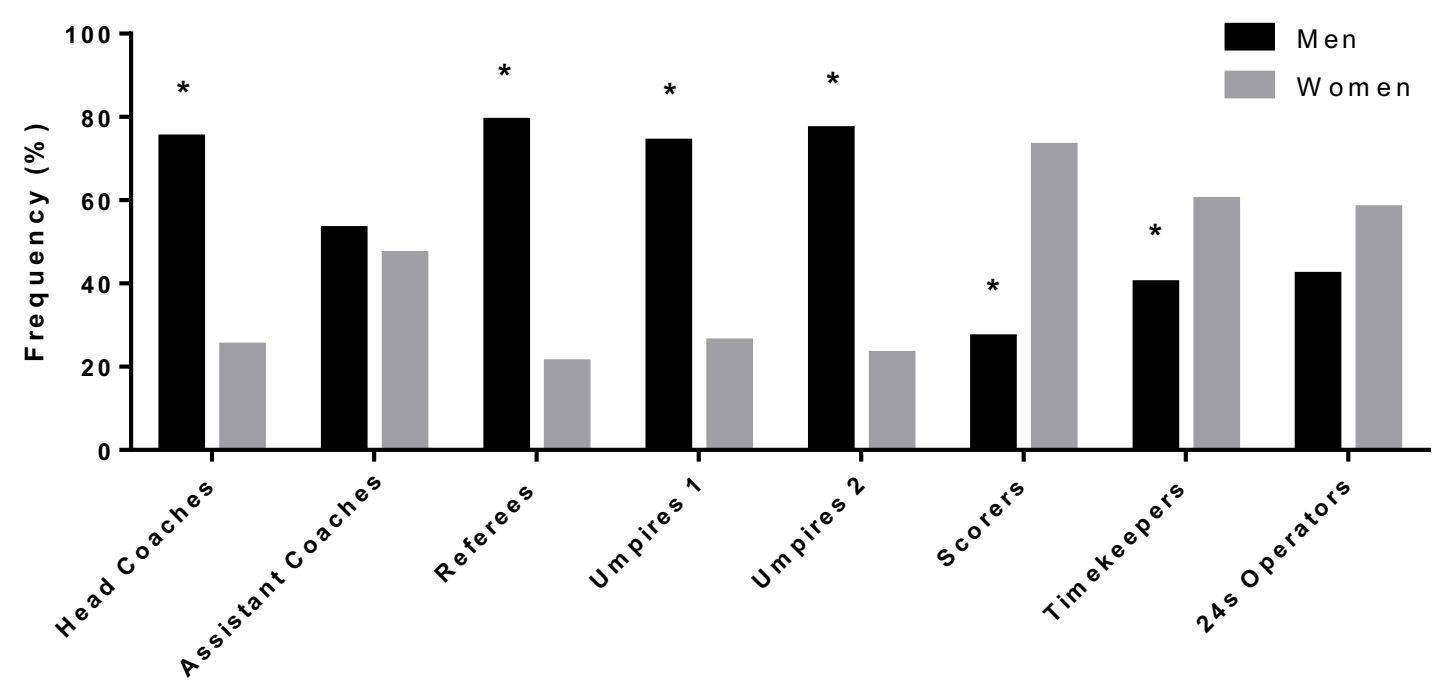

Figure 1. Frequency of men's and women's participation as coaching staff and referees in the Brazilian Women's Basketball League, from 2010 to 2017 . Legend: * Statistically significant difference between men and women in $\chi^{2}$ test (D.F. $=1 ; \alpha=0.05)$.

Figure 2 shows the frequency of women's participation as coaching staff and referees throughout the seven seasons. No increase in women's participation was found for head coach, scorer, timekeeper and $24 \mathrm{~s}$ operator, over the years. On the other hand, women's participation as assistant coach was found to decrease from $88 \%$ (2010) to $34 \%$ (2017). Only the positions of referee, umpire 1 and umpire 2 showed an increase in women's participation in the past seven years. 
(In)equality in coaching and referee in the Brazilian women's basketball
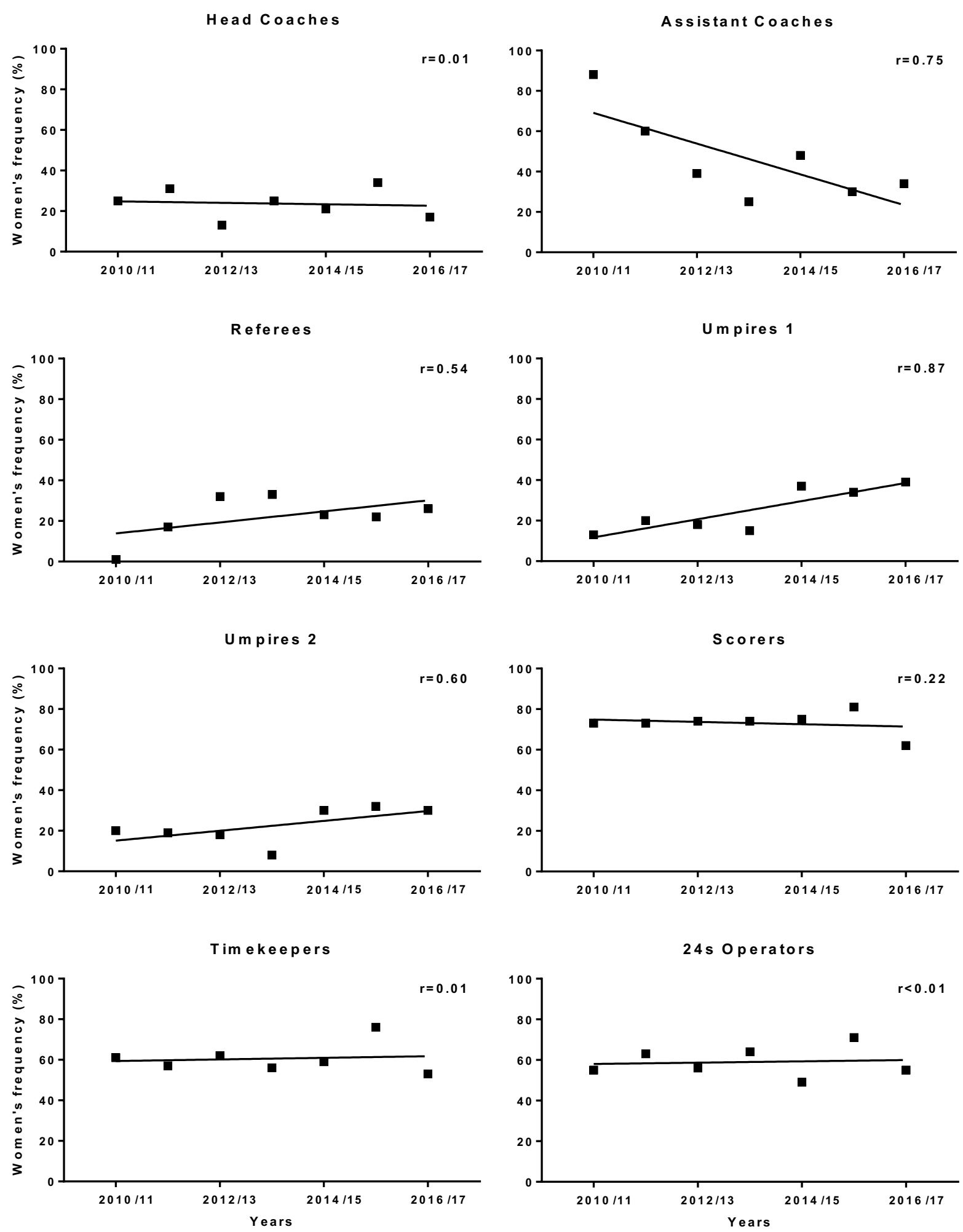

Figure 2. Frequency of women's participation as coaching staff and referees throughout the seven seasons of Brazilian Women's Basketball 


\section{Passero, J. G., Barreira, J., Caldeirani Junior, A., Galatti, L. R.}

\section{DISCUSSION}

In this study, we investigated the participation of women as coaching staff and members of the referee crew in the Brazilian Women's Basketball League from 2010 to 2017. Although the period of eight years (seven seasons) is a short timeframe to find significant changes in the male-dominated sports workplace, the results of this study lead to a critical analysis of the (under)representation of female professionals in the Brazilian women's basketball context. We found that women represent $24 \%$ of the Brazilian basketball head coaches, and this proportion has remained stable over the past years. This data may be interpreted as a "pessimistic" or "optimistic" result, depending on the reference used in the analysis. In the United States $57.4 \%$ of the head coaches in women's basketball are female (Walker \& Bopp, 2010), which makes the Brazilian scenario an alarming context, regarding the opportunities to develop and qualify female coaches. On the other hand, previous studies showed that only $7 \%$ of the Brazilian head coaches in different sports are female (Ferreira et al., 2013), which makes the women's basketball context a less unequal workplace regarding gender issues. Similarly, Welch and Sigelman (2007) found in Division I Women's Sports that women coaches are more prevalent in basketball than in three other team sports. These results suggest that women's basketball is a sport in which women achieve a higher proportion of head coaching positions, compared to other women's sports.

Independent of adopted perspective, the realistic analysis of our data reveals that coaching is still a male-dominated profession. The literature has suggested several constraints faced by women to become coaches. Specifically in Brazil, Ferreira et al. (2013) investigated the factors associated with the female underrepresentation in coaching positions. The authors interviewed thirteen coaches from eight sports and, according to the participants, Brazil is still a very sexist country, where prejudice is still strong. Women coaches also perceived that the conception of women being the "fragile" sex still persists in the sports workplace. In addition, the authors found the lack of opportunities for the insertion and ascension of women, in sports leadership positions. As a last factor, it was found that the lack of recognition and low incomes faced by female coaches lead them to seek other jobs (Ferreira, Anjos, Drigo, Mourão, \& Salles,
2018; Ferreira et al., 2013). As suggested by previous studies, the culture of sports reinforces the gender power structure of the society. As long as society continues to support the inferior role of women in sports, women will continue to face unequal representations in leadership positions in sports (Walker \& Bopp, 2010).

An alarming finding of our study is the decrease in women's participation as assistant coaches, from $88 \%$ (2010/2011) to 34\% (2016/2017). Similar results were found in the United States, where the proportion of women coaching female teams has dropped from $90 \%$ to $43 \%$, after Title IX was set (Acosta \& Carpenter, 2002, 2010). According to the authors, these data demonstrate that as women's sports have become more important, men have developed more interest in developing a career in them. It may be speculated that the higher the visibility and competitiveness of the Brazilian Women's Basketball League, the higher the interest will be for men to participate in this workplace. The increased interest and participation of men in leadership positions in women's sports, coupled with the lack of representation and opportunities for women's insertion and qualification in sports, may lead to a decrease in women representation in sports leadership positions, throughout the years. This is problematic, because the increased number of female players in the past years does not guarantee a higher interest amongst women in developing a career in sports leadership. This may be due to the lack of female role-models in sports.

This study brought new insights to the literature investigating the proportion of women in referee positions. We found an increase in female participation as referee, umpire 1 and umpire 2 throughout the years, although men still have a significantly higher participation in these positions. On the other hand, we found a higher number of women as scorer, timekeeper and $24 \mathrm{~s}$ operator, compared to men, and these proportions appear stabilized over the years. We could explain these results by the phenomenon called a "glass ceiling." The expression has often been used to describe invisible barriers through which women can see elite positions but cannot reach them (Ragins, Townsend, \& Mattis, 1998). The "glass ceiling" affect is evidenced by fewer women in the occupations of referee, umpire 1 and 2 compared to the women in the 


\section{(In)equality in coaching and referee in the Brazilian women's basketball}

occupations of scorer, timekeeper and $24 \mathrm{~s}$ operator position. This invisible barrier can be related to association between authority and masculinity, which persists in both society and in sports (Norman, 2010b). Therefore, even with the increased participation of women in sports, the results of this study corroborate that female participation is still restricted by the basis of the hierarchical sports pyramid.

Although our investigation in the Brazilian women's basketball league has added insights into the phenomenon of the (under)representation of women professionals in female sports, it is important to recognize the limitations of this study. The first limitation lies in the method used in data collection. Although quantitative data provide a valuable overview of women's participation in coaching and referee positions, qualitative information is needed to provide a better understanding of this complex phenomenon. Secondly, the longitudinal approach of increasing women's statistical representation does not guarantee that working conditions, barriers and prejudices have been overcome over the past years, which once more reinforces the need for complementary qualitative data. Finally, and as stated earlier, the eight-year time period used in this study is a short time to reveal the power changes in the sports context. Still, the results and discussion of this study may provide valuable information for future studies into this research topic.

\section{PRACTICAL APPLICATION}

Although women's participation in sports, and specifically in elite Brazilian basketball, has been increasing over the past years, the findings of this study showed that sports leadership for women is still restricted to positions of less visibility. Men still mostly occupy the positions of leadership, as head coaches and referees. This research evidences the need for the debate and proposal of policies to promote female participation in different management positions in basketball. Changes need to be implemented in order to abolish the institutionalized access discrimination that women face in sports. This study suggests two ways to increase women's representation in sports leadership positions. First, policies should be developed to ensure that women are offered a fair opportunity for employment in sports. In this way, it is fundamental that Brazilian national and regional federations create opportunities for women to qualify as coaches, assistant coaches and referees. Secondly, conferences and meetings should be created and promoted for women, in which female professionals can share experiences and learn from one another's skills.

\section{REFERENCES}

1. Acosta, R. V., \& Carpenter, L. J. (2002). Women in intercollegiate sport: A longitudinal study-Twenty-five year update 1977-2002. Unpublished manuscript, Brooklyn College, Brooklyn, New York.

2. Acosta, R. V., \& Carpenter, L. J. (2010). Women in intercollegiate sport: A longi- tudinal, thirtyone year update 1977-2010.Unpublished manuscript, Brooklyn College, Brooklyn, New York.

3. Cohen, J. (1988). Statistical Power Analysis for the Behavioral Sciences (2nd ed.). Hillsdale: Erlbaum.

4. Cunningham, G. B., \& Sagas, M. (2002). The differential effects of human capital for male and female division I basketball coaches. Research Quarterly for Exercise and Sport, 73(4), 489-495. https://doi.org/10.1080/02701367.2002.1060905 1

5. Darvin, L., \& Sagas, M. (2017). An Examination of Homologous Reproduction in the Representation of Assistant Coaches of Women's Teams: A 10-Year Update. Gender Issues, 34(2), 171-185. https://doi.org/10.1007/s12147-0169169-2

6. Everhart, C. B., \& Chelladurai, P. (1998). Gender Differences in Preferences for Coaching as an Occupation: The Role of Self-Efficacy, Valence, and Perceived Barriers. Research Quarterly for Exercise and Sport, 69(2), 188-200. https://doi.org/10.1080/02701367.1998.1060768 3

7. Fasting, K. (2000). Female and male coaches in the eyes of female elite soccer players. European Physical Education Review, 6(1), 91-110. http://journals.sagepub.com/doi/pdf/10.1177/135 6336X000061001

8. Fernández, F. R., \& Ventura, K. E. (2007). Mujeresen lós órganos de gobierno de las 


\section{Passero, J. G., Barreira, J., Caldeirani Junior, A., Galatti, L. R.}

organizaciones desportivas españolas 2002-2006. Madrid: Comissão Mulher e Esporte, Comitê Olímpico Espanhol.

9. Ferreira, H. J., Anjos, L. A. dos, Drigo, A. J., Mourão, L. N., \& Salles, J. G. D. C. (2018). Barriers faced by brazilian female coaches. Revista Brasileira de Educação Física e Esporte, 31(2), 479-488. https://doi.org/10.11606/18075509201700020479

10. Ferreira, H. J., Salles, J. G. C., Mourão, L., \& Moreno, A. (2013). A baixa representatividade de mulheres como técnicas esportivas no Brasil. Movimento, 19(3), 103-124. https://doi.org/10.22456/1982-8918.29087

11. Forbes, A., Edwards, L., \& Fleming, S. (2015). 'Women can't referee': exploring the experiences of female football officials within UK football culture. Soccer \& Society, 16(4), 521-539. https://doi.org/10.1080/14660970.2014.882829

12. Galatti, L. R., Paes, R. R., Machado, G. V., Gonçalves, C. B., Seoane, A. M., Galatti, L. R., Seoane, A. M. (2015). Determinantes de excelência no basquetebol feminino: as conquistas da seleção Brasileira na perspectiva das atletas. Revista Da Educação Física/UEM, 26(4), 621632.

https://doi.org/10.4025/reveducfis.v26i4.26424

13. Jones, C., \& Edwards, L. L. (2013). The woman in black: Exposing sexist beliefs about female officials in elite men's football. Sport, Ethics and Philosophy, 7(2), 202-216. https://doi.org/10.1080/17511321.2013.777771

14. Hargreaves, J. (1994). Sporting females : critical issues in the history and sociology of women's sports. London: Routledge.

15. Kalin, J. L., \& Waldron, J. J. (2015). Preferences Toward Gender of Coach and Perceptions of Roles of Basketball Coaches. International Journal of Exercise Science, 8(4), 303-317.

16. Kane, M. J., \& Stangl, J. M. (1991). Employment Patterns of Female Coaches in Men's Athletics: Tokenism and Marginalization as Reflections of Occupational Sex-Segregation. Journal of Sport and Social Issues, 15(1), 21-41. https://doi.org/10.1177/019372359101500102
17. Kanter, R. M. (1993). Men and women of the corporation. BasicBooks.

18. Kilty, K. (2006). Women in Coaching. The Sport Psychologist, 20(2), 222-234. https://doi.org/10.1123/tsp.20.2.222

19. Norman, L. (2010a). Bearing the Burden of Doubt. Research Quarterly for Exercise and Sport, 81(4), 506-517. https://doi.org/10.1080/02701367.2010.1059971 2

20. Norman, L. (2010b). Feeling second best: Elite women coaches' experiences. Sociology of Sport Journal, 27(1), 89-104. https://doi.org/10.1123/ssj.27.1.89

21. Novais, M. C. B. (2018). “À beira do gramado ou fora do jogo?": as treinadoras do futebol de mulheres no Brasil. Dissertação de mestrado. Universidade Federal de Juiz de Fora (UFJF). Retrieved from https://repositorio.ufjf.br/jspui/handle/ufjf/7097

22. Ragins, B. R., Townsend, B., \& Mattis, M. (1998). Gender gap in the executive suite: CEOs and female executives report on breaking the glass ceiling. Academy of Management Perspectives, 12(1), $28-42$. https://doi.org/10.5465/ame.1998.254976

23. Reade, I., Rodgers, W., \& Norman, L. (2009). The Under-Representation of Women in Coaching: A Comparison of Male and Female Canadian Coaches at Low and High Levels of Coaching. International Journal of Sports Science \& Coaching, 4(4), 505-520. https://doi.org/10.1260/174795409790291439

24. Sartore, M. L., \& Cunningham, G. B. (2007). Explaining the Under-Representation of Women in Leadership Positions of Sport Organizations: A Symbolic Interactionist Perspective. Quest, 59(2), 244-265.

https://doi.org/10.1080/00336297.2007.1048355 1

25. Stangl, J. M., \& Kane, M. J. (1991). Structural Variables That Offer Explanatory Power for the Underrepresentation of Women Coaches Since Title IX: The Case of Homologous Reproduction. Sociology of Sport Journal, 8(1), 47-60. https://doi.org/10.1123/ssj.8.1.47 


\section{(In)equality in coaching and referee in the Brazilian women's basketball}

26. Theberge, N. (1993). The Construction of Gender in Sport: Women, Coaching, and the Naturalization of Difference. Social Problems, 40(3), 301-313. https://doi.org/10.2307/3096881

27. Vargas, L. de F., Caputo, E. L., \& Silva, M. C. da. (2017). Caracterização do perfil dos treinadores de futsal feminino de equipes que disputam os Jogos Abertos de Pelotas. RBFF - Revista Brasileira de Futsal e Futebol, 9(33), 151-159.

28. Walker, N. A., \& Bopp, T. (2010). The Underrepresentation of Women in the MaleDominated Sport Workplace: Perspectives of Female Coaches. Journal of Workplace Rights, 15(1), 47-64. https://doi.org/10.2190/WR.15.1.d

29. Walker, N., Bopp, T., \& Sagas, M. (2011). Gender Bias in the Perception of Women as Collegiate Men's Basketball Coaches. Journal for the Study of Sports and Athletes in Education, 5(2), 157176. https://doi.org/10.1179/ssa.2011.5.2.157

30. Welch, S., \& Sigelman, L. (2007). Who's calling the shots? Women coaches in division i women?s sports. Social Science Quarterly, 88(5), 1415$1434 . \quad$ https://doi.org/10.1111/j.15406237.2007.00509.x

31. Wellman, S., \& Blinde, E. (1997). Homophobia in women's intercollegiate basketball: Views of women coaches regarding coaching careers and recruitment of athletes. Women in Sport and Physical Activity Journal, 6(2), 63-82. https://doi.org/10.1123/wspaj.6.2.63

32. Wolf, E. (2017). De jogadoras a treinadoras: mulheres rompendo o teto de vidro. Universidade Federal do Rio Grande do Sul. Escola de Educação Física, Fisioterapia e Dança. Curso de Educação Física: Bacharelado. Retrieved from https://lume.ufrgs.br/handle/10183/174706BayHinitz, A.K., Peterson, R.F. y Quilitch, H.R. (1994). Cooperative games: A way to modify aggressive and cooperative behaviors in young children. Journal of Applied Behavior Analysis, 27(3), 435-446.

33. Carbelo, B. (2006). Estudio del sentido del humor: validación de un instrumento para medir el sentido del humor, análisis del cuestionario y su relación con el estrés. (Tesis doctoral). Universidad de Alcalá, Madrid.
34. Coll, C. (2010). Desarrollo, aprendizaje y enseñanza en la Educación Secundaria. Barcelona: Graó.

35. González, J., Caprara, G. V., Garcés de los Fayos, E. J. y Zuffianó, A. (2014). Importance of the development of prosocial behavior in the adolescent's personality through physical education. En Physical Education: Role of School. Programs, Children's Attitudes and Health Implications. NOVA SCIENCE PUBLISHERS. New York. 